Rev. Int. Contam. Ambie. 35 (4) 991-998, 2019

DOI: 10.20937/RICA.2019.35.04.17

\title{
EFFECT OF RAW GLYCEROL ON PLANT SOIL SYSTEM IN CORN AND SORGHUM PLANTS
}

Efecto de la glicerina cruda sobre el sistema suelo-planta en el cultivo de maíz y sorgo

\author{
Carmen BETANCOURT ${ }^{1 *}$, Renato DE MELLO PRADO ${ }^{2}$, Leonides CASTELLANOS ${ }^{3}$, \\ Dilier OLIVERA VICIEDO ${ }^{2}$ and Jonás PEREIRA DE SOUZA Jr. ${ }^{2}$
}

\footnotetext{
${ }^{1}$ Centro de Estudios para la Transformación Agraria Sostenible, Universidad de Cienfuegos, Cuba

${ }^{2}$ Facultad de Ciencias Agrarias y Veterinarias, Universidad Estadual Paulista (FCAV/UNESP). Carretera de acceso Profesor Paulo Castellane, s/n, Jaboticabal, San Pablo, Brasil. CP 14884-900

${ }^{3}$ Facultad de Ciencias Agrarias, Universidad de Pamplona, Campus Principal. Carretera a Bucaramanga $\mathrm{km}$ 1. Pamplona, Norte de Santander, Colombia

*Corresponding author: carmenbetancouert@gmail.com
}

(Received: July 2018; accepted: February 2019)

Key words: biodiesel, dehydrogenase, dry biomass, foliar nitrogen, salinity

\begin{abstract}
The raw glycerol obtained from the production of biodiesel contains salts and impurities that can generate negative impacts when applied to the soil, however, mixing them with solutions of nitrogen fertilizers could be a viable solution. The objective of this investigation was to evaluate the effect of glycerol on the system soil-plant, in two crops, corn (Zea mayz L.) and sorghum (Sorghum bicolor L.). The study was conducted in 2016 at the Sao Paulo State University UNESP- Jaboticabal, Brazil. The experiments were prepared in a design totally randomized in a factorial arrangement 2 x 3 with four repetitions. The studied factors were soil: Argisol (Hapludox) and Latosol (Haplustox) and fertilization (without fertilizer, urea and urea + glycerol). At 60 days of having applied the treatments, the electric conductivity (EC) and the dehydrogenase enzyme (DH) were measured in the soil and nitrogen accumulation in aboveground (NF) and the dry biomass (DM) in the plant. Raw glycerol increased EC values in both soils, while DH, NF and DM were higher in Latosol soil. The treatment urea + glycerin increased the EC, the DH and the DM, and the urea the NF. The DH and EC media values varied per treatment and in each studied soil. For application of crude glycerol to these crops, a systematic control of the EC of the soil should be carried out as well as the implementation of agricultural practices that mitigate the salinization impact.
\end{abstract}

Palabras clave: biodiésel, biomasa seca, deshidrogenasa, nitrógeno foliar, salinidad

\section{RESUMEN}

La glicerina cruda obtenida de la producción de biodiésel contiene sales e impurezas que pueden generar impactos negativos cuando se aplica al suelo, sin embargo, su mezcla con disoluciones de fertilizantes nitrogenados pudiera ser una solución viable. El objetivo de esta investigación fue evaluar el efecto de la glicerina cruda sobre el sistema suelo-planta, en plantas de maíz (Zea mayz L.) y sorgo (Sorghum bicolor L.). El estudio se realizó en el año 2016 en la Universidad Júlio de Mesquita Filho en Brasil. 
Los experimentos fueron dispuestos en un diseño completamente aleatorizado en un arreglo factorial 2 × 3 con cuatro repeticiones. Los factores estudiados fueron tipo de suelo: Argisol (Hapludox) y Latosol (Haplustox), y fertilización (sin fertilizante, urea y urea + glicerina). A los 60 días de aplicados los tratamientos se midieron la conductividad eléctrica (EC) y la enzima deshidrogenasa (DH) en el suelo, la biomasa seca (DM) y el contenido de nitrógeno (NF) en la planta. La glicerina cruda incrementó los valores de la EC en ambos suelos, mientras la DH, el NF y la DM fueron mayores en el suelo Latosol. El tratamiento urea + glicerina incrementó la EC, la DH y la DM y la urea el NF. Los valores medios de DH y EC fueron variables entre tratamientos y entre suelos usados. Para la aplicación de glicerina cruda a estos cultivos se debe realizar un control sistemático de la EC del suelo, así como la implementación de prácticas agrícolas que mitiguen el impacto de la salinización.

\section{INTRODUCTION}

The biofuels such as biodiesel and bioethanol represent an attractive energy source, as they are constituted of renewable materials, with less potential of environmental contamination. The biofuel production it increased yearly with the proper increase in its main by-product: raw glycerol, that has a low commercial potential (Quispe et al. 2013). It has been estimated that more than two million tons of glycerol consistently reach the market every year, special attention in the scientific community has been given so the search to look for glycerol application (Betancourt et al. 2016). Some research was carried out to assess the use of glycerol in soils (Dalias and Polycarpou 2014).

The application of raw glycerol in soil can have negative impacts that should be studied. This byproduct contains salts (which vary in proportion according to the production process) and impurities such as methanol, amongst others (Tan et al. 2013). The salt content could affect the soil salinity and the impurities, such as methanol and the precipitated solids, affect soil microbial life (Sarma et al. 2012) and soil quality (Singh et al. 2014).

The adverse effects of salinity can vary according to the vegetal species and the developmental state with the time of exposure and the saline concentration and with the nature of the salts present in the growing environment. Higher salt content causes an increase in soil solution osmotic pressure (Arslan and Demir 2013), since plant roots extract water through osmosis, the water uptake of plants decreases. Also, salt content could inhibit the nutrients absorption necessary for the crops growth (Guerrero-Padilla 2015).

Soil microorganisms and enzymatic activity are essential in determining the soil organic matter decomposition, nutrient cycling, soil degradation (Mahajan et al. 2016) and the soil fertility (Preethi et al. 2013).
Among these microbiological and biochemical factors, soil enzymes have been suggested as potential indicators of soil quality due to their biological nature, simple measurement and rapid response to changes in soil management when compared to other biological properties (Ling et al. 2010). The dehydrogenase enzyme (DH) is a good indicator to know the biogeochemical cycles that occur in the soil. DH is one of the main components of soil enzymatic activity participating and guarantees the correct sequence of all the biochemical processes (Kumar et al. 2013).

The aim of this study was to assess the effect of raw glycerol on the system soil-plant, in two crops, corn (Zea mayz L.) and sorghum (Sorghum bicolor L.).

\section{MATERIAL AND METHODS}

The study was carried out in the second half of the year 2016 in a greenhouse located in Sao Paulo State University UNESP, in Jaboticabal-SP, Brazil ( $21^{\circ} 15^{\text {' }}$ $19^{\prime \prime} \mathrm{S}$ e $48^{\circ} 19^{\prime} 21^{\prime \prime} \mathrm{L}$, and at an altitude of $615 \mathrm{~m}$ ). For its conduction, two experiments were carried out: one with sorghum plants (Sorghum bicolor L.) and another with corn plants (Zea mayz L.)

Both experiments were conducted in a completely randomized design in a factorial arrangement $3 \times 2$. The first factor (F1) was soil types Argisol (Hapludox) and Latosol (Haplustox), and the second factor (F2) fertilization with three types of treatment; T1: without fertilization (control), T2: urea and T3: urea + glycerol. Each treatment was repeated four times for a total of 24 experimental units which were propylene pots of five and six $\mathrm{dm}^{3}$ capacities, for the plants of sorghum and corn, respectively. Ten seeds were planted in each pot and after the emergency only four plants were left. 
Urea was applied in T2 at a concentration of $400 \mathrm{mg} / \mathrm{dm}^{3}$ of $\mathrm{N}$ in the form of urea $(45 \% \mathrm{~N})$. Glycerol used in T3 was a residual of the biodiesel producer industry and contained $0.6 \%$ sodium $(\mathrm{Na})$ (Díaz et al. 2016). Fluid urea was added to this glycerol until it contained $20 \%$ of nitrogen and the doses applied to both crops were $0.4 \mathrm{~mL} / \mathrm{dm}^{3}$ (urea + glycerol). In all the cases, watering was applied twice a day to keep humidity at $60 \%$ of field capacity.

Physical-chemical assays were carried out before the conduction of the study in order to know the soil characteristics (Table I); later phosphorus (P) (400 $\mathrm{mg} / \mathrm{dm}^{3}$ ) was applied as simple superphosphate and potassium $(\mathrm{K})\left(300 \mathrm{mg} / \mathrm{dm}^{3}\right)$ as potassium chloride. Agricultural lime was added to the Latosol in order to increase base saturation until $65 \%(\mathrm{~V})$ and to reach the same value in both soils. Soil sample collection was taken in the column of soil (from top to bottom) in order to determine electric conductivity (EC) and dehydrogenase enzyme (DH). The soil was well mixed and representative portions were taken from the entire column to measure both DH and EC. For determining EC, $100 \mathrm{~g}$ of soil were weighted and $100 \mathrm{~mL}$ of deionized water were added. This sample was agitated during 30 seconds every half an hour during five hours. It was filtered and EC was measured using a conductivity meter CM 20S TOA.

$\mathrm{DH}$ was determined following the method of Casida et al. (1964) by the reduction of 2,3,5-triphenyl tetrazolium chloride (TTC). Soil (3 g) was incubated for $24 \mathrm{~h}$ with TTC at $30^{\circ} \mathrm{C}$. The triphenyl formazan (TPF) formed was extracted with ethanol and measured spectrophotometrically at $546 \mathrm{~nm}$. Dehydrogenase activity was expressed as $\mu \mathrm{gTPF} / \mathrm{g}$ dry soil.

Nitrogen accumulation aboveground (NF) was determined following the criteria proposed by Bataglia (1983). In order to determine the dry biomass (DM), aerial biomass of plants were collected and then placed in a hotbed of forced circulation until a constant mass was obtained. The variables EC, DH,
NF and DM were measured at $60^{\text {th }}$ day of treatments' application.

A variance analysis of two factors was applied to EC, DH, NF and DM. Data were evaluated using Asistat (Silva and Azevedo 2009) statistics software. Means were compared by the Tukey test $(\mathrm{p}<0.01)$.

\section{RESULTS}

\section{Effect of fertilization in EC, DH, NF and DM in the corn (Zea mays L.) plant soil system}

In corn crops DM, DH and EC were significantly different $(p<0.01)$ between soils. All the variables measured had significant differences $(p<0.01)$ regarding fertilization factor. Significant interaction was observed between the two factors (soil and treatment) for EC and DH, but not for NF and DM (Table II). The soil type did not have influence in NF, but the fertilization factor did have. The plants treated with urea and non-fertilized ones had the highest and lowest NF values respectively (Table III).

At $44^{\text {th }}$ day of applying the treatments a process of chlorosis was observed in non-fertilized plants. Chlorosis was initiated in the old leaves, and through the days, this process was extended to all leaves and plants. The same chlorosis pattern was observed in the plants treated with urea + glycerol in the final days of the experiment.

DM highest values were registered in Latosol, and with urea and urea + glycerol treatments $(\mathrm{p}<$ 0.01) (Table III). In these fertilization treatments DM values were similar ( $p>0.01$ ), so the addition of glycerol did not affect this variable.

The interaction observed between soil and fertilization factors affected in a different way EC values. Highest values of this indicator were recorded in the Argisol $(\mathrm{p}<0.01)($ Table IV). EC values were also related to the effect of fertilization, the treatment with urea + glycerol generated the highest EC values in

TABLE I. PHYSICAL-CHEMICAL CHARACTERISTICS OF SOILS BEFORE THE START OF THE EXPERIMENT

\begin{tabular}{|c|c|c|c|c|c|c|c|c|c|}
\hline \multirow{2}{*}{$\begin{array}{l}\text { Type } \\
\text { of soil }\end{array}$} & \multirow{2}{*}{$\begin{array}{c}\mathrm{pH} \\
\left(\mathrm{CaCl}_{2}\right)\end{array}$} & $\mathrm{OM}^{*} \mathrm{P}$ & S & $\mathrm{Al}$ & $\mathrm{H}+\mathrm{Al}$ & $\begin{array}{l}\text { Addition } \\
\text { of bases }\end{array}$ & CCI** & \multirow{2}{*}{$\begin{array}{c}\text { Sat.*** } \\
\text { Bases } \\
(\mathrm{V} \%)\end{array}$} & \multirow{2}{*}{$\begin{array}{c}\text { Sat. } \\
\text { Al } \\
(\mathrm{m} \%)\end{array}$} \\
\hline & & \multicolumn{3}{|c|}{$\mathrm{g} / \mathrm{dm}^{3}$} & \multicolumn{3}{|c|}{$\mathrm{Mmol} / \mathrm{dm}^{3}$} & & \\
\hline Latosol & 5.0 & 12 & 8 & 2 & 22 & 15.8 & 38.0 & 41 & 10 \\
\hline Argisol & 5.4 & 4 & 6 & 1 & 13 & 23.5 & 36.1 & 65 & 4 \\
\hline
\end{tabular}

*Organic biomass, ** Cation-exchange capacity, *** Saturation 
TABLE II. ANALYSIS OF VARIANCE, F TEST FOR DIFFERENT INDICATORS IN THE CORN PLANTS: NITROGEN ACCUMULATION IN ABOVEGROUND (NF), DRY BIOMASS (DM), ELECTRIC CONDUCTIVITY (EC) AND DEHYDROGENASE (DH) AT 60 DAYS AFTER TREATMENTS

\begin{tabular}{lcccc}
\hline Factors & $\begin{array}{c}\mathrm{EC} \\
\mu \mathrm{S} / \mathrm{cm}\end{array}$ & $\begin{array}{c}\mathrm{DH} \\
\mu \mathrm{g} \text { TFF/g } 24 \mathrm{~h}\end{array}$ & $\begin{array}{c}\mathrm{NF} \\
\mathrm{mg} / \mathrm{plant}\end{array}$ & $\begin{array}{c}\mathrm{DM} \\
\mathrm{g} / \mathrm{plant}\end{array}$ \\
\hline \multicolumn{5}{c}{ F Values } \\
\hline Soil & $79.5^{* *}$ & $164.5^{* *}$ & $5.28^{\mathrm{ns}}$ & $10.5^{* *}$ \\
Fertilization & $130.1^{* *}$ & $34.8^{* *}$ & $20.6^{* *}$ & $5.3^{*}$ \\
Fertil soil & $12.9^{* *}$ & $26.9^{* *}$ & $3.5^{\mathrm{ns}}$ & $0.5^{\mathrm{ns}}$ \\
Coefficient of variation (\%) & 10.5 & 11.6 & 12.5 & 10.4 \\
\hline
\end{tabular}

** significant $(\mathrm{p}<0.01) *$ significant $(\mathrm{p}<0.05),{ }^{\text {ns }}$ (Non-significant level)

TABLE III. VALUES OF NITROGEN ACCUMULATION IN ABOVEGROUND (NF) AND DRY BIOMASS (DM), AT 60 DAYS AFTER TREATMENTS

\begin{tabular}{lcc}
\hline Simple factors & NF mg/plant & DM g/plant \\
\hline & Soil \\
\hline Latosol & $0.828 \mathrm{a}$ & $47.5 \mathrm{a}$ \\
Argisol & $0.592 \mathrm{a}$ & $41.1 \mathrm{~b}$ \\
\hline \multicolumn{3}{c}{ Fertilization } \\
\hline Without fertilization & $0.363 \mathrm{~b}$ & $39.9 \mathrm{~b}$ \\
Urea & $1.153 \mathrm{a}$ & $47.5 \mathrm{a}$ \\
Urea + Glycerol & $0.615 \mathrm{~b}$ & $462 \mathrm{a}$ \\
\hline
\end{tabular}

Different letters in each column indicate significant differences $(\mathrm{p}<0.01)$

both soil types $(\mathrm{p}<0.01)$ (Table IV). Urea treatment also generated an increase in EC, with the highest value in the Argisol $(\mathrm{p}<0.01)$.
The interaction between soil and fertilization factors also affected the DH concentrations (Table IV). Although the lowest value of DH in the Argisol was obtained with urea treatment, similar to Latosol soil (Table IV). No significant differences were found between the treatments for $\mathrm{DH}$ values $(\mathrm{p}>0.01)$ in Argisol.

The highest value of DH $(\mathrm{p}<0.01)$ was registered in Latosol soil with urea + glycerol treatment.

\section{Effects of fertilization in EC, DH, NF and DM in the sorghum (Sorghum bicolor L.) plant soil system}

There were significant differences $(p<0.01)$ 60 days after the onset of the experiment for the factor soil in $\mathrm{DH}$ and $\mathrm{EC}(\mathrm{p}<0.05)$. The variables $\mathrm{NF}$ and DM were similar in both soils. For the factor fertilization, the variables EC and DH showed significant differences $(\mathrm{p}<0.01)$; meanwhile NF and DM did not show differences amongst treatments. The interaction of both factors for EC and DH were significant $(p<0.01)$, but not for NF and DM (Table V). Soil and treatment factors did not

TABLE IV. AVERAGE VALUES OF ELECTRIC CONDUCTIVITY (EC) AND DEHYDROGENASA (DH) FOR THE INTERACTION OF SOIL FACTORS AND FERTILIZATION IN THE CORN PLANTS

\begin{tabular}{lccrrrr}
\hline & \multicolumn{2}{c}{$\mathrm{EC}(\mu \mathrm{S} / \mathrm{cm})$} & & \multicolumn{2}{c}{$\mathrm{DH}(\mu \mathrm{g}$ TFF $/ \mathrm{g} 24 \mathrm{~h})$} \\
\cline { 2 - 3 } \cline { 6 - 7 } & \multicolumn{2}{c}{ Latosol } & Argisol & & \multicolumn{1}{c}{ Latosol } & Argisol \\
\hline Without fertilization & $172.3 \mathrm{bC}$ & $715.5 \mathrm{aC}$ & & $169.5 \mathrm{aB}$ & $88.22 \mathrm{bA}$ \\
Urea & $789.5 \mathrm{bB}$ & $916.5 \mathrm{aB}$ & & $95.6 \mathrm{aC}$ & $78.03 \mathrm{aA}$ \\
Urea + Glycerol & $993.3 \mathrm{bA}$ & $1242.5 \mathrm{aA}$ & & $200.3 \mathrm{aA}$ & $83.06 \mathrm{bA}$ \\
\hline
\end{tabular}

Different lower-case letters within each variable indicate differences in soil $(\mathrm{p}<0.01)$

Different capital letters within each variable indicate differences in fertilization treatments 
have influence on DM, neither NF concentrations for sorghum plants $(\mathrm{p}>0.01)$ (Table VI). In this crop chlorosis was not observed.

TABLE V. ANALYSIS OF VARIANCE, F TEST FOR DIFFERENT INDICATORS IN THE SORGHUM PLANTS: NITROGEN ACCUMULATION IN ABOVEGROUND (NF), DRY BIOMASS (DM), ELECTRIC CONDUCTIVITY (EC) AND DEHYDROGENASE (DH) AT 60 DAYS AFTER TREATMENTS

\begin{tabular}{lcccc}
\hline Factors & $\begin{array}{c}\mathrm{EC} \\
\mu \mathrm{S} / \mathrm{cm}\end{array}$ & $\begin{array}{c}\mathrm{DH} \\
\mu \mathrm{g} \mathrm{TFF} / \mathrm{g} \\
24 \mathrm{~h} \mathrm{~h}^{-1}\end{array}$ & $\begin{array}{c}\mathrm{NF} \\
\mathrm{mg} / \mathrm{plant}\end{array}$ & $\begin{array}{c}\mathrm{DM} \\
\mathrm{g} / \mathrm{plant}\end{array}$ \\
\hline \multicolumn{5}{c}{$\mathrm{F}$ Values } \\
Soil & $5.1^{*}$ & $32.69^{* *}$ & $2.1^{\mathrm{ns}}$ & $3.9^{\mathrm{ns}}$ \\
Fertilization & $79.2^{* *}$ & $5.8^{* *}$ & $1.4^{\mathrm{ns}}$ & $2.3^{\mathrm{ns}}$ \\
Fertil soil & $10.5^{* *}$ & $7.4^{* *}$ & $1.47^{\mathrm{ns}}$ & $0.47^{\mathrm{ns}}$ \\
Coefficient & 9.73 & 19.6 & 14.5 & 19.6 \\
of variation & & & & \\
\hline
\end{tabular}

** significant $(\mathrm{p}<0.01) *$ significant $(\mathrm{p}<0.05),{ }^{\text {ns }}$ (Non- significant level)

TABLE VI. AVERAGE VALUES OF NITROGEN ACCUMULATION IN ABOVEGROUND (NF) OF CORN PLANTS, DRY BIOMASS (DM), AT 60 DAYS AFTER TREATMENTS

\begin{tabular}{lcc}
\hline Simple factor & $\begin{array}{c}\text { NF } \\
\text { mg/plant }\end{array}$ & $\begin{array}{c}\text { DM } \\
\text { g/plant }\end{array}$ \\
\hline Soil & \\
\hline Latosol & $31.9 \mathrm{a}$ & $15.1 \mathrm{a}$ \\
Argisol & $29.8 \mathrm{a}$ & $19.1 \mathrm{a}$ \\
\hline & Fertilization & \\
\hline Without fertilization & $0.476 \mathrm{a}$ & $14.0 \mathrm{a}$ \\
Urea & $0.477 \mathrm{a}$ & $19.0 \mathrm{a}$ \\
Urea + Glycerol & $0.588 \mathrm{a}$ & $18.2 \mathrm{a}$ \\
\hline
\end{tabular}

Different letters in each column indicate significant differences $(\mathrm{p}<0.01)$

The interaction observed between soil and fertilization factors affected $\mathrm{EC}$ values in a different way. Urea + glycerol treatment in the Latosol had the highest EC values $(\mathrm{p}<0.01)$ (Table VII). Also, control and urea treatments had not different EC values ( $p$ $>0.01$ ). The interaction observed between soil and fertilization in the sampling performed 60 days after the start of the experiment also affected the values of DH in a different way. In the Latasol, all treatments showed different DH values $(\mathrm{p}<0.01)$, non-fertilized plants and urea treatments registered the highest and lowest values, respectively, meanwhile in the Argisol there was no difference between treatments $(p>0.01)$. The highest values of DH $(p<0.01)$ were observed in Latosol, similar to the pattern in the corn crop (Table VII).

\section{DISCUSSION}

\section{Effect of fertilization in CE, DH, NF and DM in the corn (Zea mayz L.) plant soil system}

The different NF values between control and the fertilization treatments were related to the urea effects. Mineralization of urea is a necessary process because it provides a bioavailable source of nitrogen (Chilón-Camacho 2018). A nitrogen deficiency can be recognized by yellow leaves, since chlorophyll disappears from the leaves; this happens first in the lower (older) leaves at the bottom of the plant (Prado 2008). We observed progressive chlorosis related to nitrogen deficiency, starting at older leaves and subsequently reaching all leaves.

The similarity observed in the DM values between urea and urea + glycerol treatments revealed that the addition of glycerol did not affect the dry biomass, as have been found in raw glycerol application (14\%) by Díaz et al. (2016) in beet crops (Beta vulgaris L.).

The highest DM values $(\mathrm{p}<0.01)$ in the Latosol were related to physical-chemical characteristics of this soil (Table I). In it, organic matter (OM) was three times higher than OM in the Argisol. According to Medina-Méndez et al. (2017), OM provides multiple benefits to the soil, as a nutrients supply, influencing positively on crop yield.

The highest EC value in the urea + glicerine treatment is attributed to the high saline content of raw glycerol described by several authors (Sarma et al. 2012, Betancourt et al. 2016, Díaz et al. 2016). The highest values of EC in the Argisol $(p<0.01)$ were, according to EC values of its control, four times higher than in the control of the Latosol (Table IV). Also, the increase in EC after the urea treatment is related to urea in soil, because is rapidly hydrolyzed due the urease enzyme and, for each molecule of urea, two ammonia ions are formed (Sherlock and Goh 1985). The ammonia formed, as well as its following transformations in nitrate and nitrite (Ghaly and Ramakrishnan 2013) have a ionic 
TABLE VII. AVERAGE VALUES OF SOIL INTERACTION FACTORS AND FERTILIZATION ON THE ELECTRIC CONDUCTIVITY (EC) AND DEHYDROGENAS (DH) IN THE SORGHUM PLANTS

\begin{tabular}{lcccccc}
\hline & \multicolumn{2}{c}{$\mathrm{EC}(\mu \mathrm{S} / \mathrm{cm})$} & & \multicolumn{2}{c}{$\mathrm{DH}(\mu \mathrm{g} \mathrm{TFF} / \mathrm{g} 24 \mathrm{~h})$} \\
\cline { 2 - 3 } \cline { 6 - 7 } & \multicolumn{2}{c}{ Latosol } & Argisol & & Latosol & Argisol \\
\hline Without fertilization & $614.50 \mathrm{bC}$ & $776.25 \mathrm{aB}$ & & $101.21 \mathrm{aA}$ & $43.93 \mathrm{bA}$ \\
Urea & $1122.50 \mathrm{aB}$ & $858.50 \mathrm{bB}$ & & $57.53 \mathrm{aC}$ & $47.52 \mathrm{aA}$ \\
Urea + glycerol & $1389.25 \mathrm{aA}$ & $1223.50 \mathrm{bA}$ & & $80.91 \mathrm{aB}$ & $48.87 \mathrm{bA}$ \\
\hline
\end{tabular}

Different lower-case letters within each variable indicate differences in soil $(\mathrm{p}<0.01)$

Different capital letters within each variable indicate differences in fertilization treatments $(p<0.01)$

nature that generate an increase of EC in the soil (Chilón-Camacho 2018). Urea is useful as a source of nitrogen when it is added considering plant needs, but its continuous use can affect the physical, chemical and biological soil properties (Chilón-Camacho 2018), as an increase of $\mathrm{pH}$ (Hargrove 1988).

The lowest DH values with urea tratment in the Latosol (Table IV) can be attributed to urea decomposition. The increase in $\mathrm{pH}$ favors the formation of ammonia that corresponds to a lost of nitrogen, at the same time it becomes toxic for the microbiota when retained in the soil. The ammonia formed can constitute $50 \%$ of the added urea, during the months when the maximum temperature of soil is $25^{\circ} \mathrm{C}$ (Rawluk et al. 2001). In this study, carried out in summer, temperature was above $35^{\circ} \mathrm{C}$. The experimental conditions in the pots could provoke the retention of the formed ammonia with the consequent decrease of the concentration of the enzyme.

The highest DH values in the urea + glycerol treatment in the Latosol were related to the contribution of raw glycerol to the soil fertility due to the positive impact of glycerol in the development of microorganisms (Betancourt et al. 2016). Additionally, in the Latosol used in this research the OM values were found to be thrice higher to those found in the Argisol (Table I). OM increases the microbial biomass and the enzymatic activity in the soil (Mahajan et al. 2016), aspects that agree with the results obtained in this research.

\section{Effect of fertilization in the CE, DH, NF and DM in the sorghum (Sorghum bicolor $\mathrm{L}$.) plant soil system}

The highest EC values in the urea + glycerol treatment in the Argisol with sorghum plants, were also related to the high saline content of glycerol, already explained. The difference in EC values between the control and the urea treatment can be attributed to the mineralization of urea, similar to the results obtained with corn plants.

According to Ayers and Westcot (1976), sorghum and corn crops yields decrease in $10 \%$ when the soil $\mathrm{EC}$ value is higher than $2500 \mu \mathrm{S} / \mathrm{cm}$. Highest EC value (in urea + glycerol treatment) was $1389.25 \mu \mathrm{S} /$ $\mathrm{cm}$, likely, this variable probably had no influence on these sorghum and corn plants. Chilón-Camacho (2018) states that continued use of urea increases the EC of the soil due to the accumulation of salts, which causes an increase in osmotic pressure that gradually generates the plasmolysis effects, affecting the root cells of plants and killing the beneficial soil microorganisms. Due to the increase in the EC of soil, it is advisable that use of glycerol combined with urea as a fertilizer be implemented using agricultural practices to mitigate this impact.

The highest DH values for T1 (control) in Latosol respect to Argisol can also be associated to the OM influence (Table I), similar to the results observed in the corn crop. OM increases soil fertility and constitutes an energy source for microorganisms (Mahajan et al. 2016), which can cause the high $\mathrm{DH}$ values.

The lower DH concentration in sorghum plants respect to corn crop, can be associated to the fact that at the $6^{\text {th }}$ day of the treatment, sorghum plants were attacked persistently by a plague of insects. A foliar application of malathion insecticide was necessary, during all the stages of growth. This could affect the soil microbial biomass and the production of $\mathrm{DH}$, whose values are frequently used for infer the effects of pesticides in soil (Kumar et al. 2013). According to Morugán et al. (2015), the use of herbicides can modify the function and structure of the microbial community of the soil and consequently the dehydrogenase enzime activity. 


\section{CONCLUSIONS}

In the treatment applied to the corn and sorghum plants cultivated in a polyethylene pots with two different soil types (Latosol and Argisol), an interaction between the studied factors (soil types and fertilization) was found for the variables dehydrogenase and electric conductivity measured in the soil. The differences observed between the media values in DH and EC amongst the non-fertilized plants, the treatment with urea and with urea + glycerol were not the same in Argisol and Latosol.

In both crops the application of crude glycerol increase the concentration of DH in Latosol and salinity for both soils. This study revealed that when applying crude glycerol to the soil, a systematic control of soil salinity must be carried out, combined with agricultural practices that mitigate the impact of salinization.

Regarding DH, the reatment with urea increases salinity in both soils and decreased the concentrations of the enzyme. For foliar nitrogen, there were only significant differences between the treatments applied to the corn crop. DH content in the plants grown in both soils increased with the application of the treatments urea and urea + glycerol.

The DM of the corn plants showed the highest values when treatments with urea and urea + glycerol were applied, while for the growth of sorghum the studied factors did not influence the DM values.

\section{ACKNOWLEDGMENTS}

This research was supported by the International Project (Capes-Mes) that provided a postdoctoral scholarship to C.B.A It was developed in the Sao Paulo State University (UNESP-Jaboticabal, Brazil). We thank Luiz Assis for the support to the researchers.

\section{REFERENCES}

Arslan H. and Demir. Y. (2013). Impacts of seawater intrusion on soil salinity and alkalinity in Bafra Plain, Turkey. Environ. Monit. Assess. 185 (2), 1027-1040. DOI: $10.1007 / \mathrm{s} 10661-012-2611-3$

Ayers R. S. and Westcot D. W. (1976). Water quality for irrigation. Irrigation and Drainage Paper 29. Food and Agriculture Organization. Rome, Italy, 97 pp.

Bataglia O.C., Furlani A.M.C., Teixeira J.P.F, Furlani P.R. and Gallo J.R. (1983). Métodos de análise química de plantas. Campinas: Instituto Agronômico. Saint Paul, Brazil, 48 pp.
Betancourt C., Prado de Mello R., Castellanos L. and Campos C. (2016). Características de la glicerina generada en la producción de biodiesel, aplicaciones generales y su uso en el suelo. Cultivos Tropicales 37 (3), 7-1.

DOI: $10.13140 /$ RG.2.1.4329.2403

Casida Jr. L.E., Klein D.A. and Sntoro D. (1964). Soil dehydrogenase activity. Soil Science 98 (6), 371-378. DOI: 10.1097/00010694-196412000-00004

Chilón-Camacho E. (2018). Fuentes de origen, propósito y diferencias entre los conocimientos occidental y no occidental andino de la fertilidad de suelos. Apthapi 4 (2), 1168-1187.

Dalias P. and Polycarpou P. (2014). Decomposition of the biodiesel by-product, crude glycerol, in soil. Res. Agr. Eng. 60 (1), 17-23.

Díaz A., de Mello Prado R., Silva C., Castellanos L., Everlon C.R., Súarez C. and Barbosa da Silva J.G. (2016). Glycerin and potassium on soil microbial activity and nutrition and production of beet (Beta vulgaris L.). Agrociencia 50 (6), 759-768.

Ghaly A.E. and Ramakrishnan V. V. (2013). Nitrification of urea and assimilation of nitrate in saturated soils under aerobic conditions. American Journal of Agricultural and Biological Sciences 8 (4), 330-342.

DOI: 10.3844/ajabssp.2013.330.342

Guerrero-Padilla A.M. (2015). Demanda hídrica y calidad de agua de uso agrícola de la cuenca del río Jequetepeque, Perú. Agrociencia 35 (2), 5-18.

Hargrove W.L. (1988). Soil, environmental, and management factors influencing ammonia volatilization under field conditions. In: Ammonia volatilization from urea fertilizers (B.R. Bock and D. E. Kissel, Eds.). National Fertilizer Development Centre, Muscle Shoals, Alabama, USA, pp. 17-36.

Kumar S., Chaudhuri S. and Maiti S.K. (2013). Soil dehydrogenase enzyme activity in natural and mine Soil. A Review. Middle East J. Sci. Res. 13 (7), 898-906. DOI: 10.5829/idosi.mejsr.2013.13.7.2801

Ling D.J., Huang Q.C., Ouyang Y. (2010). Impacts of simulated acid rain on soil enzyme activities in a Latosol. Ecotoxicol. Environ. Saf. 73 (8), 1914-1918. DOI: 10.1016/j.ecoenv.2010.07.024

Mahajan G. R., Manjunath B. L., Singh N. P., Ramesh R., Verma R. R., Latare A. M., D'Souza R., Barnes N. and Kulkarni R. (2016). Effect of organic and inorganic sources of nutrients on soil microbial activity and soil organic carbon build-up under rice in west coast of India. Arch. Agron. Soil Sci. 63 (3), 414-426. DOI: $10.1080 / 03650340.2016 .1213813$

Medina-Méndez J., Galvis-Espínola A., Santiago-Cruz M. J., Volke-Haller V. and Cortes-Flores J.I. (2017). Incremento de la materia orgánica del suelo sobre 
el rendimiento del mango en Luvisoles, Campeche, México. Agron. Mesoam. 28 (2), 499-508.

DOI: $10.15517 / \mathrm{ma} . v 28 \mathrm{i} 2.22236$

Morugán A., García F. and Cerdà A. (2015). Changes in soil microbial activity and physicochemical properties in agricultural soils in Eastern Spain. Spanish Journal of Soil Science 5 (3), 201-213.

DOI: 10.3232/SJSS.2015.V5.N3.02

Prado de Melo R. (2008). Nutrición de plantas. Editora UNESP. Jaboticabal, Saint Paul, Brazil, 400 pp.

Preethi B., Poorniammal R., Balachandar D., Karthikeyan S., Chendreyan K., Bhattacharyya P., and Adhya T.K. (2013). Long-termorganic nutrient managements foster the biological properties and carbon sequestering capability of a wetland rice soil. Arch. Agron. Soil Sci. 59 (12), 1607-1624.

DOI: $10.1080 / 03650340.2012 .755260$

Quispe C.A.G., Coronado C.J.R. and Carvalho J.A. (2013). Glycerol: Production, consumption, prices, characterization and new trends in combustion. Renew. Sust. Energ. Rev. 27 (C), 475-493.

DOI: $10.1016 /$ j.rser.2013.06.017

Rawluk C.D.L., Grant C.A. and Racz G.J. (2001). Ammonia volatilization from soils fertilized with urea and varying rates of urease inhibitor NBPT. Can. J. Soil Sci. 81 (2), 239-246.

DOI: $10.4141 / \mathrm{S} 00-052$
Sarma S.J., Brara S.K. and Bitt E. (2012). Microbial hydrogen production by bioconversion of crude glycerol: A review. Int. J. Hydrogen Energy 37 (8), 6473-6490. DOI: 10.1016/j.ijhydene.2012.01.050

Sherlock R.R. and Goh K.M. (1985). Dynamics of ammonia volatilization from simulated urine patches and aqueous urea applied to pasture. II. Theoretical derivation of a simplified model. Fertil. Res. 6 (1), 3-22. DOI: $10.1007 / \mathrm{BF} 01058162$

Silva F.A.S. and Azevedo C.A.V. (2009). Principal components analysis in the software Assistat-Statistical Attendance. Memories of $7^{\text {th }}$ World Congress on Computers in Agriculture: American Society of Agricultural and Biological Engineers. Reno-NV-USA. 22-24 June 2009.

Singh R. N., Tripathi S., Sharma S. and Choudhary G. (2014). Influence of biodiesel effluent on physicochemical characteristics of black soil: a laboratory study. Water Air and Soil Pollut. 225 (9), 1-5. DOI: 10.1007/s11270-014-2091-x

Tan H.W., Abdul A.R. and Aroua M.K. (2013). Glycerol production and its applications as a raw material: A review. Renew. Sust. Energ. Rev. 27 (C), 118-127. DOI: 10.1016/j.rser.2013.06.035 